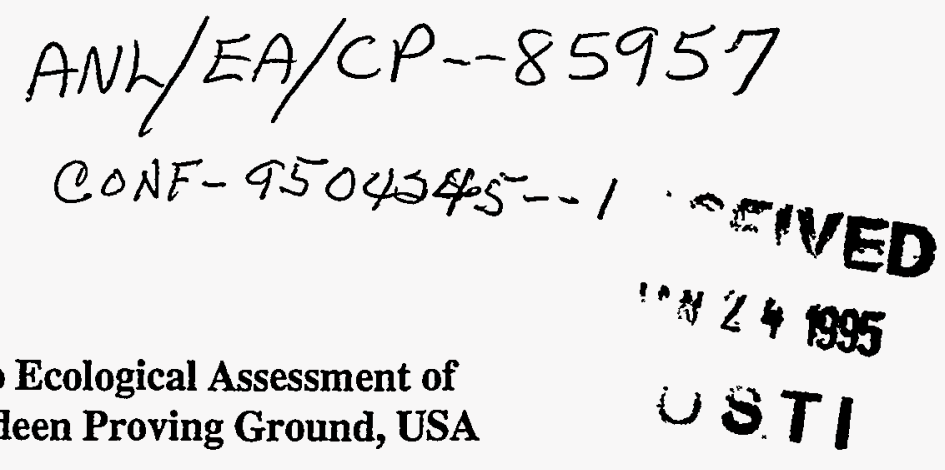

R.G. Kuperman

Environmental Assessment Division

Argonne National Laboratory

Argonne, mlinois, USA

for publication in:

New Approaches to the Development of

Bioindicator Systems for Soil Pollution

proceedings of:

NATO Advanced Research

Workshop on Bioindication

Moscow, Russia

April 24-28, 1995

The submitted manuscript has been authored by a contractor of the U. S. Government under contract No. W-31-109-ENG-38.

Accordingly, the U.S. Government retains a

nonexclusive, royalty-free license to publish

or reproduce the published form of this

contribution, or allow others to do so, for

U.S. Government purposes.

North Atlantic Treaty Organization

DISTRIBUTION Sm






\section{DISCLAIMER}

This report was prepared as an account of work sponsored by an agency of the United States Government. Neither the United States Government nor any agency thereof, nor any of their employees, makes any warranty, express or implied, or assumes any legal liability or responsibility for the accuracy, completeness, or usefulness of any information, apparatus, product, or process disclosed, or represents that its use would not infringe privately owned rights. Reference herein to any specific commercial product, process, or service by trade name, trademark, manufacturer, or otherwise does not necessarily constitute or imply its endorsement, recommendation, or favoring by the United States Government or any agency thereof. The views and opinions of authors expressed herein do not necessarily state or reflect those of the United States Government or any agency thereof. 


\title{
A HIERARCHICAL APPROACH TO ECOLOGICAL ASSESSMENT OF CONTAMINATED SOUS AT ABERDEEN PROVING GROUND, USA
}

\author{
R.G. KUPERMAN \\ Argonne National Laboratory, Environmental Assessment Division \\ 9700 South Cass Avenue, Argonne, IL 60439, USA
}

\section{Abstract}

Despite the expansion of environmental toxicology studies over the past decade, soil ecosystems have largely been ignored in ecotoxicological studies in the United States. The objective of this project was to develop and test the efficacy of a comprehensive methodology for assessing ecological impacts of soil contamination. A hierarchical approach that integrates biotic parameters and ecosystem processes was used to give insight into the mechanisms that lead to alterations in the structure and function of soil ecosystems in contaminated areas. This approach involved (1) a thorough survey of the soil biota to determine community structure, (2) laboratory and field tests on critical ecosystem processes, (3) toxicity trials, and (4) the use of spatial analyses to provide input to the decision-making process. This methodology appears to offer an efficient and potentially cost-saving tool for remedial investigations of contaminated sites.

\section{Introduction}

The field of environmental toxicology has expanded in the past decade; however, most progress has been in studies of aquatic and aboveground terrestrial ecosystems. With few exceptions, soil ecosystems have been ignored in ecotoxicological studies, and in many conceptual models they are presented as a "black box." This may be due to the immense complexity of soil ecosystems and the interdependence of the diverse soil community and the processes it regulates in soil. Methods of studying soil ecosystems have been developed [4] and used by a relatively small group of soil ecologists and are not readily available to environmental toxicologists. Because soil is a net sink for many pollutants and the functioning of the overall terrestrial ecosystem is dependent on soil processes (organic matter decomposition and release of nutrients), it is clear that a comprehensive methodology is needed to enable researchers to accurately assess damage to the soil ecosystem, while providing practical information to decision makers to direct site cleanup and remedial efforts. 
The proposed methodology is based on a hierarchical approach to assessing the ecological condition of contaminated soils. The methodology incorporates population, community, and ecosystem parameters. The focus of this methodology is on determining changes in the abundance and diversity of soil biota and changes in the rates of critical ecosystem processes that may be affected by soil contamination.

A four-step approach was used to implement a comprehensive assessment program:

1. A thorough survey of soil biota to determine community structure and whether contaminated media are toxic to area biota.

2. Laboratory and field tests on critical ecosystem processes to identify biologically mediated processes in soil most at risk from site contamination.

3. Toxicity trials to determine the relationships between the observed ecological effects in the field and concentrations of soil contaminants.

4. The use of spatial analyses for estimating the extent of the contaminated media with significant adverse ecological effects to provide input to the development of remedial alternatives and cleanup goals.

\section{Methods}

Soil biota and biologically mediated soil processes were characterized for contaminated soil at J-Field on Aberdeen Proving Ground in Maryland, USA. The objectives were to survey the soil invertebrate community, to conduct an in situ litter decomposition assay, and to determine microbial biomass and activity in soils. A summary of assessment and measurement endpoints used for the ecological risk assessment of soil ecosystems is shown in Table 1.

Studies were conducted in the spring, summer, and fall of 1994 in the terrestrial survey grids located in the pushout area near the Toxic Burning Pits (TBTF on Figure 1) and in the local background area approximately $30 \mathrm{~m}$ away from the Toxic Burning Pits (TBTC on Figure 1). A reference site with soil parameters similar to those at J-Field was selected in Gunpowder Falls State Park, approximately $7 \mathrm{~km}$ west of J-Field. The dimensions of each survey grid were approximately $10 \mathrm{~m} \times 10 \mathrm{~m}$. Samples were collected from 10 randomly selected quadrants $(1 \mathrm{~m} \times 1 \mathrm{~m})$ in each of the survey grids. The spatial distribution of soil parameters was determined by sampling along the sitewide survey grid over the entire area of concern.

\subsection{SURVEY OF SOIL BIOTA}

Determining the abundance and diversity of soil organisms in a given soil ecosystem is a prerequisite to a comprehensive assessment program. Soil invertebrates and microorganisms are essential components of the decomposer food web, nutrient cycling, and environmental 
TABLE 1. Summary of assessment and measurement endpoints for ecological risk assessment of soil ecosystems

\begin{tabular}{|c|c|c|}
\hline Assessment Endpoint & Measurement Endpoint & Ecological Component \\
\hline \multirow[t]{4}{*}{$\begin{array}{l}\text { Community and } \\
\text { population parameters }\end{array}$} & $\begin{array}{l}\text { - Taxonomic richness } \\
\text { - Abundance/activity }\end{array}$ & $\begin{array}{l}\text { - Soil invertebrate community } \\
\text { including macroinvertebrates } \\
\text { (Lumbricidae, Gastropoda, } \\
\text { Myriapoda, Aranea, Insecta), } \\
\text { microinvertebrates (Acari, } \\
\text { Collembola, Nematoda), and } \\
\text { soil Protozoa }\end{array}$ \\
\hline & & $\begin{array}{l}\text { - Plant community composition } \\
\text { - Aboveground plant biomass }\end{array}$ \\
\hline & $\begin{array}{l}\text { Abundance of functional } \\
\text { groups (trophic structure) }\end{array}$ & $\begin{array}{l}\text { Decomposers, omnivore- } \\
\text { predators, bacterivores, } \\
\text { fungivores, and herbivores }\end{array}$ \\
\hline & $\begin{array}{l}\text { Fungal and bacterial } \\
\text { abundance and activity }\end{array}$ & $\begin{array}{l}\text { Soil microorganisms, biomass } \mathrm{N}, \\
\mathrm{CO}_{2} \text { evolution (SIR) }\end{array}$ \\
\hline \multirow[t]{3}{*}{$\begin{array}{l}\text { Effects on critical } \\
\text { biological processes }\end{array}$} & $\begin{array}{l}\text { Rates of organic matter } \\
\text { decomposition and } \\
\text { nutrient release }\end{array}$ & Litter of Phragmites australis \\
\hline & Nitrogen mineralization & Field incubations \\
\hline & Enzyme activity & $\mathrm{C}-, \mathrm{N}-$, and $\mathrm{P}$-acquiring enzymes \\
\hline
\end{tabular}

SIR = substrate-induced respiration.

contaminant pathways. They are important agents in the formation and maintenance of the biological, chemical, and physical character of soil ecosystems. Soil biota play a key role in regulating the rates of organic matter degradation and the subsequent release of nutrients.

\subsubsection{Soil Macroinvertebrates}

Three soil cores (9.5-cm diameter and 10-cm depth) were collected with a stainless steel soil sampler in each sampling quadrant on each sampling date. The intact soil was placed in a sorting tray. Animals were extracted from samples by hand sorting and were preserved in ethyl alcohol for further identification. Abundance of soil macroinvertebrates was expressed as the number per square meter (to a depth of $10 \mathrm{~cm}$ ). Statistical analyses included analysis of variance (ANOVA) on the log-transformed data. The Bonferroni $t$-test was used to determine significance at the $\alpha=0.05$ level between pairs of test groups. 


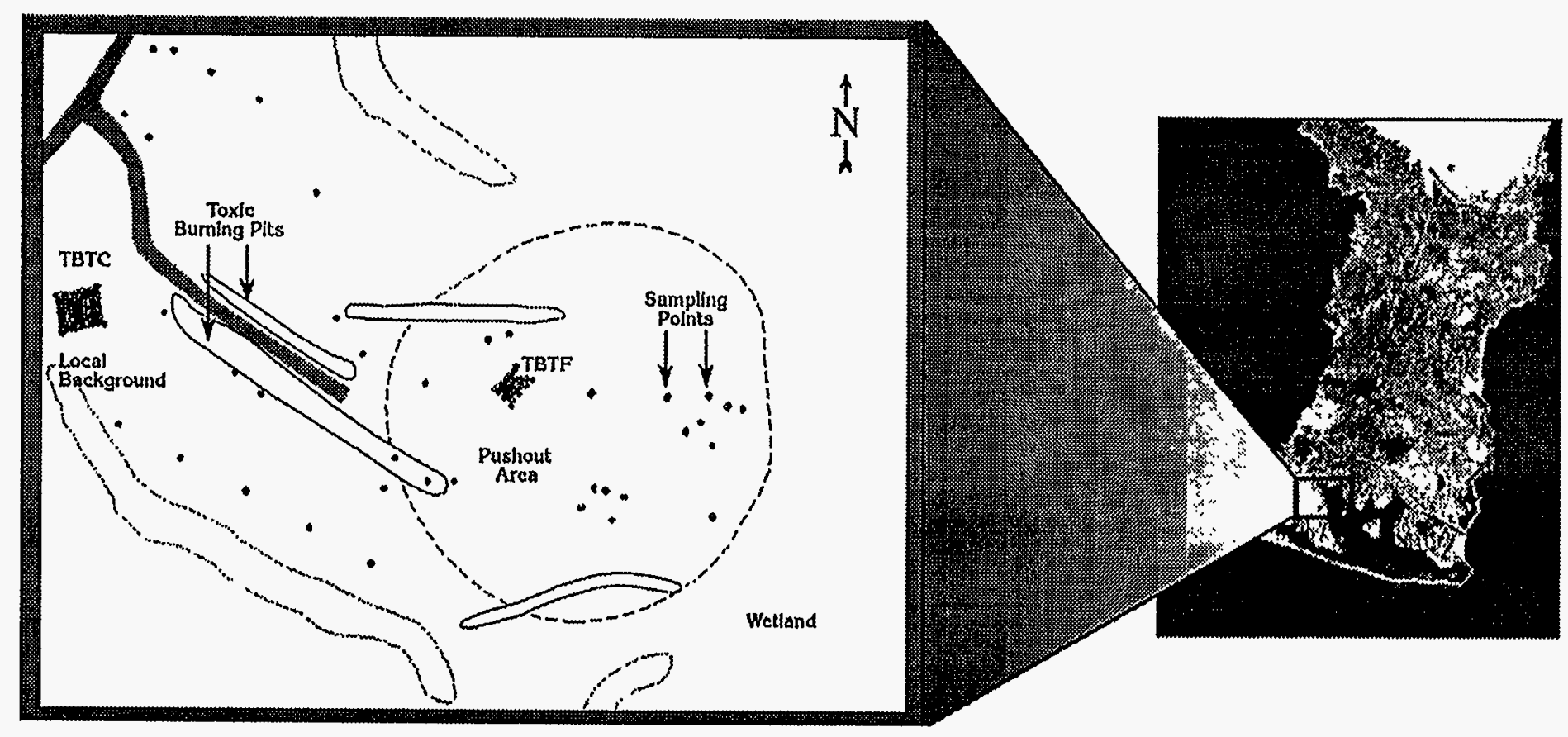

Figure 1. Map of the study area at Gunpowder Neck Peninsula 


\subsubsection{Soil Nematodes}

The Baerman funnel technique was used for extraction of nematodes from the soil. This method involves placing a soil sample on a mesh sieve at the wide part of the funnel, which has a rubber tube closed by a clip and filled with water. The nematodes move out of the soil and collect in the neck of the tube, where they can be moved into a dish for counting.

Soil cores (5-cm diameter) were taken to a depth of $10 \mathrm{~cm}$, placed in polyethylene bags, and returned to the laboratory. Twenty-gram subsamples of soil (field moist) were then placed on the extractor (Baerman funnels) for $48 \mathrm{~h}$ at room temperature. Nematodes were counted live at $140 \times$ magnification and sorted into fungivore, bacterivore, herbivore, and omnivore-predator trophic groups, on the basis of the reported feeding habits and on esophageal morphology.

\subsubsection{Direct Estimates of Active and Total Fungi and Active Bacteria}

Soil microbial biomass was estimated because of the importance of soil microorganisms in nutrient cycling and their role as a source and sink of plant nutrients at J-Field. Microbial biomass is the main acting agent for most soil biogeochemical processes. It interacts with the primary productivity of ecosystems by regulating nutrient availability and degradation pathways of soil contaminants.

For each soil sample, the length of active hyphae stained with fluorescein diacetate (FDA) was measured using epifluorescent microscopy at $250 \times$ total magnification [7]. Three separate measurements were taken from the agar film on the slide under the coverslip. Total fungal biomass was measured using the differential interference or phase-contrast microscopy at $250 \times$ total magnification. Direct estimates of active bacteria were determined using the $40 x$ objective lens and epifluorescent microscopy by counting the number of FDA-stained (i.e., active) bacteria in each of five individual fields on each slide. Statistical analyses included ANOVA. The Bonferroni $t$-test was used to determine significance at the $\alpha=0.05$ level between pairs of test groups.

\subsection{SURVEY OF BIOLOGICALLY MEDIATED PROCESSES IN SOIL}

An assessment of how increased concentrations of soil contaminants may alter rates of litter decomposition as well as the rates and timing of nutrient retention and release is critical to understanding the impact of soil pollution on the overall structure and function of J-Field terrestrial ecosystems. Litter decomposition and nutrient mineralization are important biologically mediated processes affecting soil fertility and primary productivity of ecosystems at J-Field. The distribution and turnover of organic matter contributes to ecosystem functioning by forming soil organic matter pools and nutrient exchange sites for root uptake. Soil enzyme activities and soil respiration were also measured to determine whether soil concentration of contaminants may have detrimental effects on the microbial activity in the study area. 


\subsubsection{Litter Decomposition and Nutrient Dynamics in Decomposing Litter}

Decay rates and nutrient mineralization rates of plant residues were determined in the Toxic Burning Pits area using a litterbag method. In this approach, preweighed plant residues are confined in mesh litterbags and placed in the field. Subsets of litterbags are periodically harvested to determine mass loss and change in nutrient content.

Litterbags had a $10-\mathrm{cm} \times 10-\mathrm{cm}$ inside area and were constructed of fiberglass window screen material with a mesh size of approximately $1.5 \mathrm{~mm}$. Bags were constructed by "welding" together the sides of $12-\mathrm{cm} \times 22-\mathrm{cm}$ pieces of screen (folded in half) using a flattipped soldering iron. Leaf litter of Phragmites australis in the litterbags was collected at the time of senescence in October 1993. Plant material was oven-dried at $80^{\circ} \mathrm{C}$. Litterbags were filled with 4-5 $\mathrm{g}$ of dried plant material and the exact weight recorded. The tops of filled litterbags were sealed and an aluminum tag with an identification number wired to the bag. Subsamples of dried litter were archived for initial litter quality and nutrient analyses.

Litterbags were buried in soil in an appropriate location in the terrestrial survey grids. The locations of litterbags were marked with flags. Extra litterbags were taken to the field, handled as other litterbags, but immediately returned to the laboratory to determine any loss due to handling.

Ten litterbags from each terrestrial grid were collected every six months. Litterbags were placed into labeled "zip-lock" bags as they were collected. Litter was analyzed for total nitrogen $(\mathrm{N})$ and carbon $(\mathrm{C})$ content using the Carlo/Erba NA1500 automated $\mathrm{C} / \mathrm{N}$ analyzer.

Because of contamination of plant residues with soil, residue masses were corrected for soil infiltration using the following soil correction equation [1]:

$$
F L i C=(S a \mathrm{C}-S l C) /(L i C-S i C),
$$

where $F L i C$ is the fraction of litterbag content that is actually litter $\mathrm{C} ; \mathrm{SaC}$ is the percent of $\mathrm{C}$ of the entire litterbag sample; $S l C$ is the mean percent of $\mathrm{C}$ of the soil from the field site; and $L i C$ is the percent of $C$ of the initial litter residue.

\subsubsection{Soil Enzyme Activity}

This study quantified the activity in soils of beta-glucosidase, carboxymethylcellulase (carbon-acquiring enzymes), $\mathrm{n}$-acetylglucosaminidase ( $\mathrm{N}$-acquiring enzyme), and both acid and alkaline phosphatases (phosphorus [P]-acquiring enzymes).

Soil cores were collected with a 5-cm-diameter soil corer to a depth of $10 \mathrm{~cm}$. Assays were run at $25^{\circ} \mathrm{C}$ on soil slurries suspended in $\mathrm{pH} 5$ acetate buffer. The only exceptions were the samples assayed for alkaline phosphatase activity. These slurries were suspended in buffer at $\mathrm{pH}$ 9.5. All the enzymes (except for cellulase activity) were assayed colorimetrically using pNP-linked substrates ( $\mathrm{pNP}=\mathrm{p}$-nitrophenyl). These substrates were pNP-beta-D-glucopyranoside, pNP-n-acetylglucosaminide, and pNP-phosphate. The cellulase assay was a viscometric assay that used carboxymethyl cellulose as substrate. Statistical analyses included ANOVA on the log-transformed data. A Fisher PLSD was used to determine significance at the $\alpha=0.05$ level between pairs of test groups $(n=5$ for each group). 


\subsubsection{Soil Microbial Activity}

The soil respiration study measured carbon dioxide $\left(\mathrm{CO}_{2}\right)$ evolution in microcosms as an integrator of the effects of soil contamination on the combined activities of microorganisms within the soil ecosystem. A substrate-induced respiration (SIR) method was used to estimate microbial activity in soil. The addition of substrate (glucose) to a soil sample induces a maximal respiratory response from the soil microbial biomass, measured as $\mathrm{CO}_{2}$ evolution.

Substrate-induced respiration was measured using a soil-respiration measuring system with continuous gas flow [2,3]. The soil-respiration measuring system used an incubation chamber, an air-flow-controlling unit, an air-flow-measuring unit, and a $\mathrm{CO}_{2}$ analyzer (LI-6251). A 15-g fresh homogenized subsample was placed in a 125-mL Erlenmeyer flask. Glucose solution $\left(60 \mathrm{~g} \mathrm{~L}^{-1}\right)$ was added to the flask using a syringe to bring the soil water content near to its holding capacity (no free-standing solution). Soil was incubated until the rate of $\mathrm{CO}_{2}$ evolution from the soil sample become constant at an air flow rate of $180 \mathrm{~mL}$ $\mathrm{min}^{-1}$ (approximately $40 \mathrm{~min}$ ). At this point, the $\mathrm{CO}_{2}$ evolution rate was recorded as the substrate-induced respiration of that soil sample. Statistical analyses included ANOVA. The Bonferroni $t$-test was used to determine significance at the $\alpha=0.05$ level between pairs of test groups.

\subsection{TOXICITY TRIALS}

\subsubsection{Earthworm Toxicity Tests}

Earthworm toxicity screening tests utilized the earthworm Eisenia foetida in the screening and definitive tests. Survival rates and differences between initial and final weights (sublethal endpoints) were used as indices of toxicity. The test methods used for earthworm toxicity studies were adapted from Karnak and Hamelink [8] and Neuhauser et al. [10]. Analysis of covariance (ANCOVA) was used to test the weight differences, and the $t$-test was used for pairwise comparison of least square means (means adjusted for the covariate) [12]. The screening procedures for determining earthworm toxicity are summarized by Phillips et al. [11].

\subsubsection{Phytotoxicity Tests}

The screening procedures for determining phytotoxicity were adapted from the U.S. Environmental Protection Agency's Early Seedling Growth Toxicity Test [14]. The plant species used in the screening test was lettuce (Lactuca sativa [var. Black Seeded Simpson; Meyer Seed Co., Baltimore, MD; lot B1-394]). Data were produced on seed emergence rates, plant heights, survival rates, and plant dry weights. Statistical evaluations of plant data included ANOVA and the Newman-Keuls pairwise comparison of means [12]. The screening methods for all of the plant tests are summarized by Phillips et al. [11].

\subsection{SPATIAL ANALYSES}

Spatial distributions were predicted using ordinary kriging routines. For all data, a variogram with a range of $27.5 \mathrm{~m}$ was fit to the data and the kriging routine okb2d from the 
Geostatistical Software Library [5] was used to develop a gridded data set to represent the spatial distribution of the variables. Data values were predicted on a 3-m grid spacing for each variable. Visualization of these data were created using IRIS Explorer [13]. Surfaces were developed using the northing and easting of the predicted grid, the parameter of interest for elevation, and the sum of total lead $(\mathrm{Pb})$, copper $(\mathrm{Cu})$, and zinc $(\mathrm{Zn})$ concentration for shades of grey. The images were rotated to allow the topology to be visible.

\section{Results}

All field and laboratory procedures are ongoing and cannot be fully presented in this paper. Some results from the study are reported here to illustrate the utility of the comprehensive soil assessment methodology and the advantages of a hierarchical approach for determining the ecological effects of soil contamination.

The mean total concentrations ( \pm S.E.) of seven heavy metals (arsenic, cadmium, chromium, copper, nickel, lead, and zinc) at the reference, local background, and contaminated (pushout) sites were, respectively, $1.75 \pm 0.09,7.7 \pm 0.3$, and $39.5 \pm 3.2 \mathrm{mM} \mathrm{kg}^{-1}$ dry mass of soil. Therefore, total heavy metal concentration at the local background site was 4.4 times greater than at the reference site. The contaminated site contained a total heavy metal concentration 22.5 times greater than at the reference site.

In the spring of 1994, the total abundance of macroinvertebrates was significantly $(P=0.0001)$ lower in the pushout area (TBTF) than at the local background site (TBTC). In the fall of 1994, the total abundance of macroinvertebrates did not differ significantly between the two sites, but remained significantly $(P=0.0001)$ lower than at the reference site.

Nematodes were strong indicators of soil contamination in the study area. The numbers of most trophic groups and total nematodes were significantly lower on all three dates in 1994 in the pushout area than at the local background site (Table 2). In April, all trophic groups were affected, and the total numbers of nematodes were reduced by $85 \%$ in the pushout area (TBTF) compared with the local background site (TBTC). The toxic effects on the nematode community were not as pronounced in June, but fungivore, herbivore, and hatchling groups were impacted negatively. Fungivore nematodes appeared to be particularly sensitive. The total numbers of nematodes were reduced significantly by $37 \%$ in the pushout area compared with the local background site. In October, nematodes were again significantly reduced in the pushout area compared with the local background area. All trophic groups were reduced except the herbivores. Total numbers were lower at the pushout area than at the local background and reference sites.

Microbial biomass was depressed in the local background and contaminated sites. Total fungal biomasses for the local background and contaminated sites were 54\% and 15\% that of the reference site, and active bacterial biomasses were $71 \%$ and $19 \%$ that of the reference site (Table 3). Microbial activity as measured by the substrate-induced respiration method was also reduced in polluted soils and paralleled the decrease in the microbial biomass (Table 3). 
TABLE 2. Changes in the trophic structure of soil nematodes in areas with high (pushout) and low (local background) concentrations of heavy metals

\begin{tabular}{|c|c|c|c|c|}
\hline \multirow[b]{2}{*}{ Season } & \multirow[b]{2}{*}{ Trophic Group } & \multicolumn{2}{|c|}{ Number per Gram Dry Soil } & \multirow[b]{2}{*}{$P$} \\
\hline & & $\begin{array}{l}\text { Local Background } \\
\text { (TBTC) }\end{array}$ & $\begin{array}{l}\text { Pushout Area } \\
\text { (TBTF) }\end{array}$ & \\
\hline \multirow[t]{6}{*}{ Spring } & Fungivore & 5.30 & 0.29 & 0.0001 \\
\hline & Bacterivore & 6.42 & 1.82 & 0.0012 \\
\hline & Herbivore & 2.49 & 0.10 & 0.0004 \\
\hline & Omnivore & 0.21 & 0 & 0.0160 \\
\hline & Hatchling & 0.78 & 0.05 & 0.0031 \\
\hline & Total & 15.72 & 2.41 & 0.0001 \\
\hline \multirow[t]{6}{*}{ Summer } & Fungivore & 5.11 & 0.04 & 0.0001 \\
\hline & Bacterivore & 12.99 & 12.98 & 0.3812 \\
\hline & Herbivore & 3.34 & 2.08 & 0.0565 \\
\hline & Omnivore & 0.21 & 0.04 & 0.2302 \\
\hline & Hatchling & 1.59 & 0 & 0.0001 \\
\hline & Total & 24.02 & 15.20 & 0.0567 \\
\hline \multirow[t]{6}{*}{ Fall } & Fungivore & 3.43 & 1.09 & 0.0099 \\
\hline & Bacterivore & 11.22 & 6.47 & 0.0493 \\
\hline & Herbivore & 2.36 & 4.16 & 0.8414 \\
\hline & Omnivore & 0.31 & 0 & 0.0393 \\
\hline & Hatchling & 0.85 & 0.19 & 0.0166 \\
\hline & Total & 18.60 & 12.06 & 0.0837 \\
\hline
\end{tabular}

The activity of $\mathrm{C}_{-}, \mathrm{N}-$, and $\mathrm{P}$-acquiring enzymes was significantly lower in the local background and contaminated sites than at the reference site (Table 4). The local background and contaminated sites exhibited enzyme activities that were only $14 \%-25 \%$, and $2 \%-11 \%$ those of the reference site, respectively. All enzyme activities and total fungal biomasses were significantly $(P<0.001)$ correlated for all samples. This provided greater confidence in the reliability of both enzyme and microbial data sets. 
TABLE 3. Microbial characteristics of soils in areas with high (pushout) and low (local background) concentrations of heavy metals

\begin{tabular}{lccc}
\hline \multicolumn{1}{c}{ Soil Microbial Parameter } & $\begin{array}{c}\text { Reference } \\
\text { Site }\end{array}$ & $\begin{array}{c}\text { Local } \\
\text { Background } \\
\text { (TBTC) }\end{array}$ & $\begin{array}{c}\text { Pushout } \\
\text { Area } \\
\text { (TBTF) }\end{array}$ \\
\hline $\begin{array}{l}\text { Active bacterial biomass } \\
\left(\mu \mathrm{g} \mathrm{g}^{-1} \mathrm{DW}\right)\end{array}$ & $15.37^{2}$ & $10.94^{2 \mathrm{~b}}$ & $2.89^{\mathrm{b}}$ \\
$\begin{array}{l}\text { Total fungal biomass } \\
\left(\mu \mathrm{g} \mathrm{g}^{-1} \mathrm{DW}\right)\end{array}$ & $335.27^{\mathrm{a}}$ & $182.95^{\mathrm{a}}$ & $48.96^{\mathrm{b}}$ \\
\begin{tabular}{l}
$\mathrm{SIR}\left(\mu \mathrm{g} \mathrm{CO} \min ^{-1} \mathrm{~g}^{-1}\right.$ soil DW) \\
\hline
\end{tabular} & $8.11^{\mathrm{a}}$ & $2.57^{\mathrm{b}}$ & $1.83^{\mathrm{b}}$ \\
\hline
\end{tabular}

Note: Numbers with the same letter are not significantly different at $\alpha=$

0.05 .

$\mathrm{DW}=$ dry weight.

TABLE 4. Soil enzyme activity in areas with high (pushout) and low (local background) concentrations of heavy metals

\begin{tabular}{|c|c|c|c|}
\hline Soil Enzyme & $\begin{array}{c}\text { Reference } \\
\text { Site }\end{array}$ & $\begin{array}{l}\text { Local } \\
\text { Background } \\
\text { (TBTC) }\end{array}$ & $\begin{array}{c}\text { Pushout } \\
\text { Area } \\
\text { (TBTF) }\end{array}$ \\
\hline $\begin{array}{l}\text { Beta-glucosidase } \\
\left(\mu \mathrm{M} \mathrm{g}^{-1} \mathrm{DW} \mathrm{h}^{-1}\right)\end{array}$ & $0.63^{2}$ & $0.10^{b}$ & $0.01^{c}$ \\
\hline $\begin{array}{l}\text { Carboxymethyl cellulose } \\
\text { (viscometric units } \mathrm{g}^{-1} \mathrm{DW} \mathrm{h}^{-1} \text { ) }\end{array}$ & $87.40^{2}$ & $16.30^{5}$ & $8.40^{b}$ \\
\hline $\begin{array}{l}\text { N-acetylglucosaminidase } \\
\left(\mu \mathrm{M} \mathrm{g}^{-1} \mathrm{DW} \mathrm{h} \mathrm{h}^{-1}\right)\end{array}$ & $0.27^{2}$ & $0.07^{b}$ & $0.02^{c}$ \\
\hline $\begin{array}{l}\text { Acid phosphatase } \\
\left(\mu \mathrm{M} \mathrm{g}^{-1} \mathrm{DW} \mathrm{h} h^{-1}\right)\end{array}$ & $1.78^{2}$ & $0.40^{b}$ & $0.08^{e}$ \\
\hline $\begin{array}{l}\text { Alkaline phosphatase } \\
\left(\mu \mathrm{M} \mathrm{g}^{-1} \mathrm{DW} \mathrm{h}^{-1}\right)\end{array}$ & $0.30^{2}$ & $0.12^{b}$ & $0.15^{b}$ \\
\hline $\begin{array}{l}\text { Total phosphatase } \\
\left(\mu \mathrm{M} \mathrm{g}^{-1} \mathrm{DW} \mathrm{h} \mathrm{h}^{-1}\right)\end{array}$ & $2.08^{2}$ & $0.52^{b}$ & $0.23^{\mathrm{c}}$ \\
\hline
\end{tabular}

Note: Numbers with the same letter are not significantly different at $\alpha=$ 0.05 .

$\mathrm{DW}=\mathrm{dry}$ weight. 
Litter decomposition was significantly faster at the contaminated site (pushout area) than at the background site at both 6 and 12 months (Table 5). Decay was particularly rapid at the contaminated site, and only $6 \%$ of the initial $\mathrm{C}$ remained after one year. Nitrogen dynamics of decomposing litter exhibited contrasting patterns at the two sites. At the background site, there was significantly more net $\mathrm{N}$ mineralization from litter than at the contaminated site after six months. However, by 12 months, whereas the litter at the local background site had begun to show net immobilization of $\mathrm{N}$, litter at the contaminated site had a net mineralization of $\mathrm{N}$. These results strongly suggest that at the contaminated site, litter $\mathrm{C}$ and $\mathrm{N}$ dynamics were altered, possibly through the alteration of soil biotic activity. The more rapid decay and greater net $N$ mineralization in litter at the contaminated site have yet to be explained.

The results of toxicity trials were reported by Phillips et al. [11]. A summary of the results is shown in Figure 2. The outcomes of the earthworm toxicity and the phytotoxicity tests were conflicting. Most of the earthworm toxicity tests indicated that soil was not toxic (except for two locations) in the study area. On the contrary, the phytotoxicity test showed toxic effects in all sampling locations.

The spatial distribution of the sum of $\mathrm{Pb}, \mathrm{Cu}$, and $\mathrm{Zn}$ concentrations is shown in Figure 3. An example of the spatial correlation of total enzyme activity with the sum of the concentrations of $\mathrm{Pb}, \mathrm{Cu}$, and $\mathrm{Zn}$ is given in Figure 4. Geostatistical techniques were used to determine the spatial distributions of these parameters and to evaluate various crosscorrelations. Geostatistical techniques allow the spatial correlation to be determined for two variables even when sample points were not collocated. The parameter distributions were

TABLE 5. Carbon and nitrogen dynamics in decomposing litter of Phragmites australis in areas with high (pushout) and low (local background) concentrations of heavy metals

\begin{tabular}{ccccc}
\hline $\begin{array}{c}\text { Time } \\
\text { (months) }\end{array}$ & Parameter & $\begin{array}{c}\text { Local } \\
\text { Background } \\
\text { (TBTC) }\end{array}$ & $\begin{array}{c}\text { Pushout Area } \\
\text { (TBTF) }\end{array}$ & $P$ \\
\hline 6 & \% C remaining & 39.82 & 26.37 & 0.0660 \\
12 & & 25.22 & 6.18 & 0.0001 \\
6 & Litter N content (\%) & 0.81 & 1.04 & 0.0343 \\
12 & & 1.29 & 1.60 & 0.0622 \\
6 & \% N remaining & 77.85 & 94.09 & 0.0789 \\
12 & & 108.84 & 73.01 & 0.0005 \\
\hline
\end{tabular}



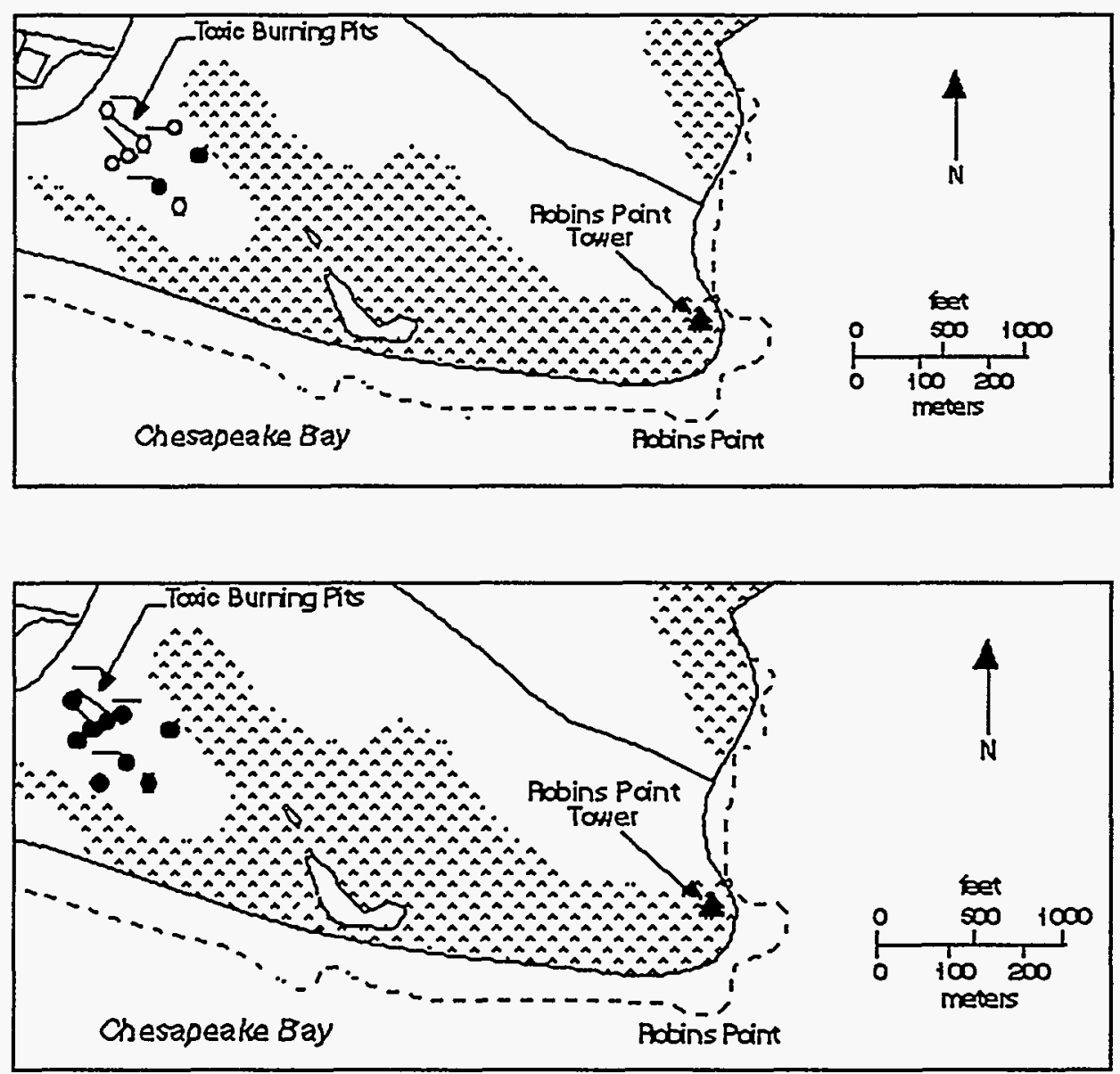

Figure 2. Earthworm toxicity screening of soils (top) and phytotoxicity screening of soils (bottom).

- toxic effect; o no toxic effect

found to be spatially correlated within themselves and negatively cross-correlated. The cross-correlation between total enzyme activity and metal concentration was analyzed using two methods: a cross-semivariogram, a standard geostatistical tool, and an interactive graphical data representation using geostatistically estimated data distributions. This estimation technique does not change sample point values and uses a least-squares minimization technique to estimate the data for display. The graphical analysis technique 


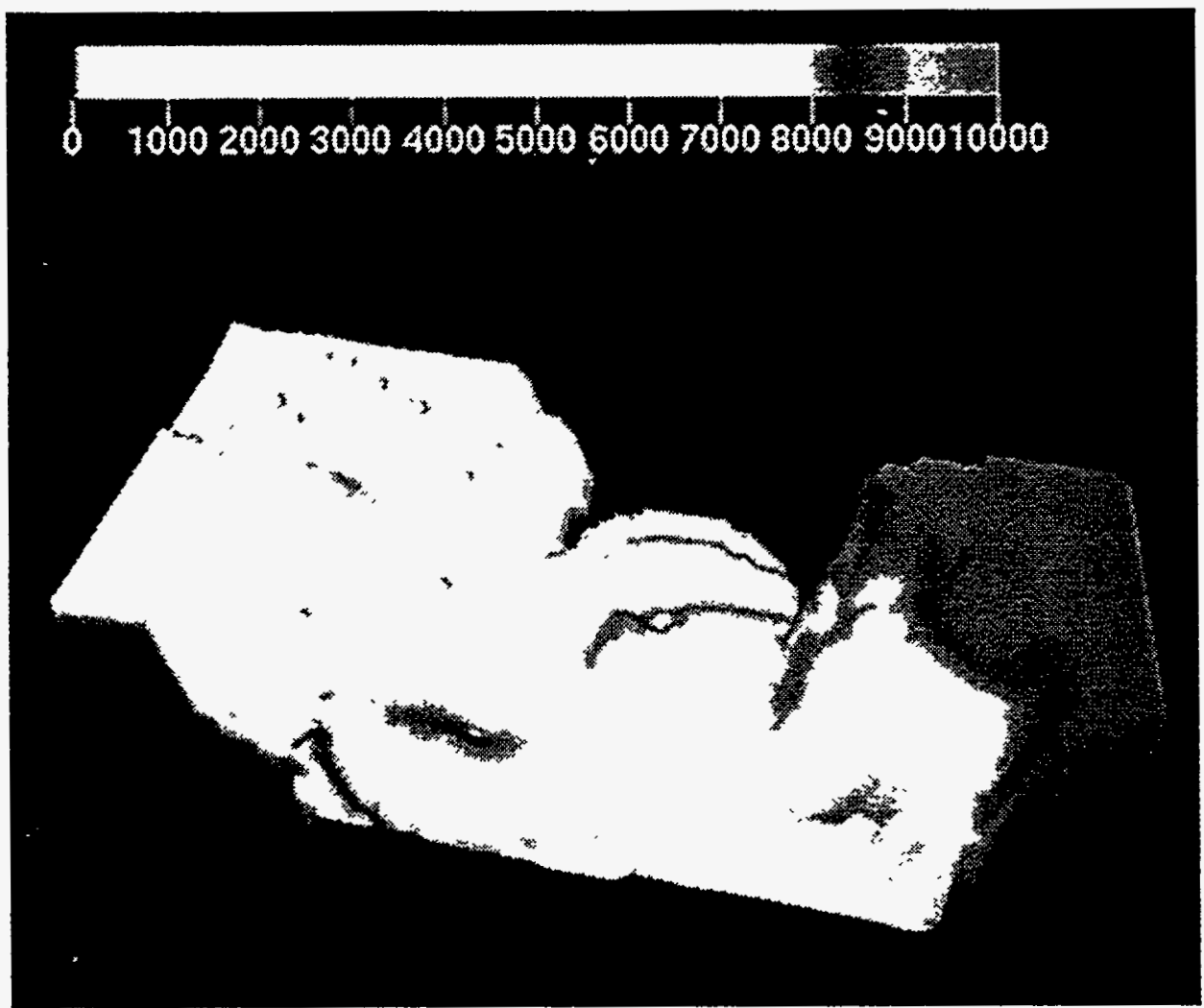

Figure 3 Spatial distribution of the sum of the concentations of $\mathrm{Pu}, \mathrm{Cu}$, and $\mathrm{Zn}$.

involves displaying a surface in three-dimensional space, the topology of which is generated by one variable (total enzyme activity) and the surface colored by a second (total metal concentration). Both the visualization technique and the cross-semivariogram showed a negative correlation between the total enzyme activity and the metal concentrations.

\section{Discussion}

This study provided an opportunity to develop and test the efficacy of a comprehensive methodology for assessing ecological risks of soil contamination. A hierarchical approach to assessment of contaminated soils incorporated several levels of ecosystem structure and allowed ascertainment of changes in the structure and function of soil communities in an 


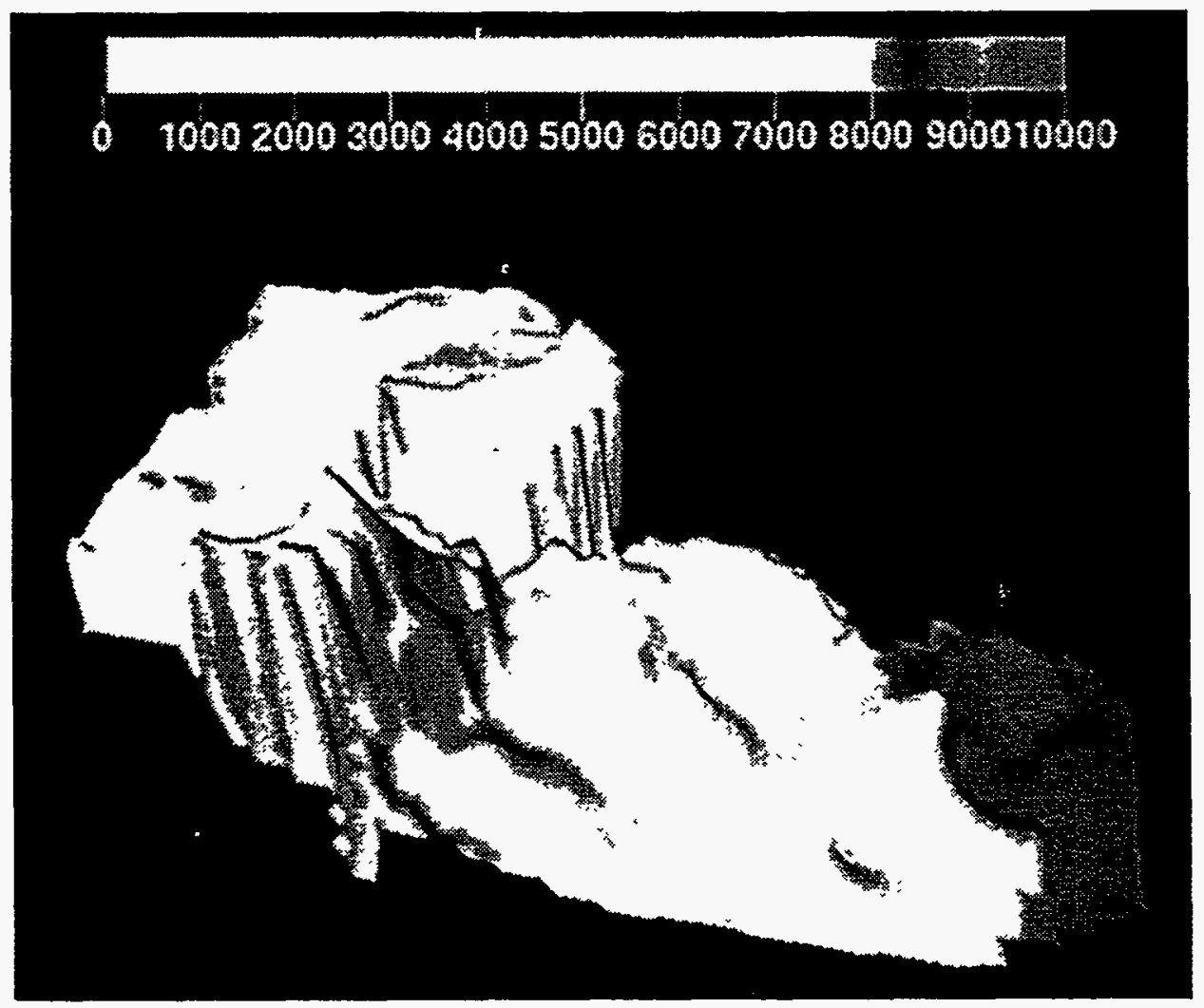

Figure 4 Spatial correlation of total enzyme activity with the sum of the concentrations of $\mathrm{Pb}, \mathrm{Cu}$, and $\mathrm{Zn}$.

area with a wide range of concentrations of heavy metals. All measured population and community parameters were affected by soil contamination with heavy metals. The numbers of soil macroinvertebrates, the abundance of trophic groups of nematodes, and the biomasses of soil microorganisms were reduced in contaminated soil.

Ecosystem processes were also sensitive to changes in the soil chemical environment. Microbial activity and $\mathrm{C}$ and $\mathrm{N}$ dynamics in decomposing litter were all considerably altered by soil contamination. Significant reduction in the activities of all enzymes closely paralleled the increase in heavy metal concentrations. Ten- to fifty-fold reductions in enzyme activities were observed as heavy metal concentrations increased. These results suggest that soil contamination with heavy metals may have detrimental effects on soil biota 
and on the rates of organic matter degradation and the subsequent release of nutrients to aboveground communities in the area.

With few exceptions (e.g., [9]), the ecological risk assessment programs used at most Superfund sites in the United States do not include any of the soil parameters used in this study. The only two official soil toxicity tests recommended by the U.S. Environmental Protection Agency [6] and commonly used in remedial investigations include an earthworm test and a phytotoxicity test (e.g., lettuce seed germination and root elongation tests). Additionally, tests originally developed for aquatic toxicology programs, including water flea (Daphnia) survival, algal growth, and fathead minnow (Pimephales) survival tests are recommended for assessing the toxicity of soil elutrates [6]. Clearly, these tests lack ecological realism regarding their capacity to adequately determine the effects of soil contamination on the structure and function of soil communities. They can also lead to conflicting results. In our study, the conclusions from the earthworm toxicity test contradicted those obtained from the phytotoxicity tests, making it difficult to provide meaningful recommendations to decision makers.

Analyses of spatial distribution of total enzyme activity (one of the ecological response variables used in this study) allowed for the delineation of the area of J-Field where significant detrimental ecological effects occurred. These data may be useful in determining the extent of cleanup activities needed in the area of concern. This information is particularly important for Superfund sites like J-Field that do not have an unrestricted-use alternative in the future. At these sites, the guidelines for concentrations of soil contaminants based on human toxicology commonly used in remedial investigations cannot apply, and the assessment of ecological effects of soil contamination may be the only acceptable option.

Our results further indicate that a hierarchical approach can be a valuable strategy in the assessment of the ecological effects of soil contamination. By integrating biotic parameters and ecosystem processes, this approach can give insight into the mechanisms that lead to alterations in the structure and function of soil ecosystems.

Acknowledgments. I am grateful to R. Parmelee, G. Williams, M. Carreiro, E. Ingham, $S$. Zoars, and R. Compte for their participation in this project. This work was supported under a military interdepartmental purchase request from the U.S. Department of Defense, Directorate of Safety, Health, and Environment, Aberdeen Proving Ground, Maryland, through U.S. Department of Energy contract W-31-109-Eng-38. 


\section{References}

1. Blair, J.M. (1988) Nitrogen, phosphorous and sulphur dynamics in decomposing deciduous leaf litter in the southern Appalachians, Soil Biology and Biochemistry 20, 693-701.

2. Cheng, W., and Coleman, D.C. (1989) "A simple method for measuring $\mathrm{CO}_{2}$ in the continued air flow modification of substrate-induced respiration technique," Soil Biology and Biochemistry 21:385-388.

3. Cheng, W., and Virginia, R.A. (1993) "Measurement of microbial biomass in Arctic tundra soils using fumigation-xtraction and substrate-induced respiration procedures," Soil Biology and Biochemistry 25:135-141.

4. Crossley, D.A., Coleman, D.C., Hendrix, P.F., Cheng, W., Wright, D.H., Beare M.H., and Edwards, C.A. (1991) Modern Techniques in Soil Ecology, Elsevier, New York.

5. Deutsch, C.V., and Joumal, A.G. (1992) GSLIB Geostatistical Software Library and User's Guide, Oxford University Press, New York.

6. Gneene, J.C., Bartels, C.L., Warren-Hicks, W.J., Parkhurst, B.R., Linder, G.L., Peterson, S.A., and Miller, W. (1988) Protocols for Short Term Toxicity Screening of Hazardous Waste Sites, EPA/600B88/029, U.S. Environmental Protection Agency, Corvallis, Ore.

7. Ingham, E.R., and Klein, D.A. (1984) Soil fungi: relationships between hyphal activity and staining with fluorescein diacetate, Soil Biology and Biochemistry 16, 273-278.

8. Kamak, R., and Hamelink, J. (1982) A standandized method for determining acute toxicity of chemicals to earthworms, Ecotoxicology Environment Safety 6, 216-222.

9. Menzie, C.A., Burmaster, D.E., Freshman, J.S., and Callahan, C.A. (1992) Assessment of methods for estimating ecological risk in the terrestrial component: a case study at the Baird and MCGuire Superfund site in Holbrook, Massachusetts, Environmental Toxicology and Chemistry 11, 245-260.

10. Neuhauser, E.F., Loehr, R.C., Malecki, M.R., Milligan, D.L., and Durkin, P.R. (1985) The toxicity of selected organic chemicals to the earthworm Eisenia fetida, Journal of Environmental Quality 14, 383-388.

11. Phillips, C.T., Checkai, R.T., and Stull, E.A. (1994) Phytotoxicity and earthworm toxicity testing of soil samples from J-Field, Aberdeen Proving Ground, Maryland, TU-7/ANLAPG/J-F/RI-ERA, Argonne National Laboratory, Argonne, Ill.

12. SAS Institute Inc. (1988) User's Guide, Version 6.03, SAS Institute Inc., Cary, N.C.

13. Silicon Graphics Inc. (1992) SGI Explorer User's Manual, Mountain View, Calif.

14. U.S. Environmental Protection Agency (1982) Environmental Effects Test Guidelines, EPA 560/6-82-002, Washington, D.C. 